\title{
Morphological features and processes in the central Algarve rocky coast (South Portugal)
}

\author{
D. Moura a, $\square$, L. Albardeiro a, C. Veiga-Pires a , T. Boski a, E. Tigano b \\ a Centro de Investigação Marinha e Ambiental (CIMA), Universidade do Algarve, Campus de Gambelas, 8005-139, Faro, Portugal \\ bDipartimento Scienze della Terra, Universitá degli Studi di Messina, Messina, Italy
}

\begin{abstract}
Morphological features along the Algarve rocky coast, South Portugal, are identified and described, with an emphasis on shore platforms and notches. The contributions of processes, such as wave attack, chemical weathering and bioerosion, to sculpting the shore platforms are discussed. The preferential localization of shore platforms on sites exposed to waves, and the lack of significant chemical weathering, point to wave erosion as the first-order factor in platform formation, whilst bioerosion/bioprotection,

lithology and geological structure determine platform morphological variations. In addition, platforms above the present intertidal zone appear to have a polygenetic evolution, being inherited from former sea-level highstands and currently undergoing chemical weathering. The occurrence of notch features is independent of the degree of exposure to waves, but they mostly occur where the substratum is sand. Hydrostatic pressure appears to be an important factor in the formation of marine caves in the more sheltered sites.
\end{abstract}

Keywords: Algarve; Rocky coast; Marine erosion; Shore platforms; Notches; Marine caves

\section{Introduction}

Although a large volume of scientific work has been developed concerning shoreline evolution and coastal processes, studies of rocky coasts, and in particular those with shore platforms, have been less frequently made than for other coastal environments. This relative scarcity of research concerning rocky coasts does not concord with their natural exposure, but may be

\footnotetext{
Corresponding author. Universidade do Algarve, FCMA-CIMA. Campus de Gambelas, 8005-139, Faro, Portugal. Tel.: +351 289 800900; fax: +351 289818353 .

E-mail addresses: dmoura@ualg.pt (D. Moura), lalbar@ualg.pt (L. Albardeiro),cvpires@ualg.pt (C.Veiga-Pires), tboski@ualg.pt (T. Boski), etigano@unime.it (E. Tigano).
}

explained by their slow responses to environmental change compared to other types of environment such as sandy coasts (Griggs and Trenhaile, 1994). Although shore platforms are a common morphological feature on rocky coasts, the first-order factors that determine their genesis remain contentious. This constitutes a challenge to ongoing investigations on shore platforms and, in particular, to studies concerning the interpretation of raised platforms. Raised platforms (shore platforms higher than the present mean sea level) have been frequently interpreted as inherited morphological features of marine abrasion during the Pleistocene highstands or as the result of emerging coasts (Bradley and Griggs, 1976; Kelsey and Bockheim, 1994; Regnauld et al., 1994; Trenhaile, 2001a,b; Chao et al., 2003). Raised 
platforms may thus represent former sea-level highstands and/or coastal uplift, or they may be formed by sub-aerial weathering. Doubts concerning the genesis and evolution of platforms mean that terms such as "abrasion platform" or "wave-cut platform" should be avoided in favour of "shore platform." Determining the genesis of such platforms is a challenge in areas where, as in the Algarve coast, several raised platforms occur but contain no marine deposits, thereby making it difficult to investigate paleo-shorelines.

Studies of shore platforms have generally focused on the relevance of weathering and wave energy on sculpting these features (Bartrum, 1916; Johnson, 1919; Wentworth, 1938; Bird and Dent, 1966; Trenhaile, 1987; Sunamura, 1996; Trenhaile, 2000; Stephenson and Kirk, 2000a,b, 2001; Trenhaile, 2001a, 2002a,b; Andrade et al., 2002; Trenhaile, 2005; Kanyaya and Trenhaile, 2005; Twidale et al., 2005). This is a topic not completely clarified because the relevant morphogenetic processes vary depending on (for example) lithology, oceanic environment and shore morphology. Sediment budget, wave energy, wave angle attack, wavelength and height, and tidal regime are all factors reported as causing major coastal morphologic changes (LaValle et al., 2001; Cooper and Pilkey, 2004; Bender and Dean, 2004; Noormets et al., 2004; Goodfellow and Stephenson, 2005). Some of these factors are controlled by coastal seabed slope, such as the breaking depth of the waves and the height at the breaking point (Noormets et al., 2004), in addition to the influence on wave refraction and how quickly the shoreline migrates. Gentle slopes produce faster shoreline migration and higher wave refraction than steeper slopes, although the quantity of sediment involved strongly influences this relation (Bender and Dean, 2004). Moreover, headlands are related to offshore shoaling, with wave energy being concentrated on those prominent coastal features where waves are higher than in the more sheltered areas (Komar, 1998). The influence of bedrock roughness on shore platform erosion must also be taken into account, as irregular surfaces induce wave refraction in a complex pattern with high turbulence intensity and shear stress (Komar, 1998; Costa et al., 2002).

Marine notches are grooves or undercuttings in bedrock of rocky coasts, produced by sea erosion, and their formation is favoured in well-cemented bioclastic limestones (Pirazzoli, 1986; Kershaw and Guo, 2001). Although several different processes may contribute to the formation of marine notches, including chemical, physical, and biological processes, when notches occur in sheltered areas with a vertical cliff face and with a low tidal range they are good indicators for mean sea level (Pirazzoli, 1986). They are common features on rocky coasts, and have been used to reconstruct sea-level fluctuations and to quantify amounts and rates of relative coastal uplift (e.g., Pirazzoli et al., 1994; Kershaw and Guo, 2001; Ramírez-Herrera et al., 2004).

The main goal of this investigation is to use field observations of shore platforms in the central Algarve rocky coast in order to characterize the first-order processes that determine their genesis. Although previous research has addressed aspects of coastal cliff retreat in the Algarve (Dias, 1988; Dias and Neal, 1992; Marques, 1997; Neves and Pereira, 1999), there is no published literature on shore platforms for this area. In this research, we quantify the geographic occurrence and morphological characteristics of platforms, notches and caves along a section of the Algarve coast, and relate these characteristics to various parameters including wave climate, wave exposure, lithology and geological structure in order to explain platform/notch/ cave development in the area.

\section{The study area}

In the Algarve region, geological formations young from north to south and generally plunge southeastward. S. Vicente Cape represents the inflexion point between north-south and west-east shoreline directions (Fig. 1). The south coastal sector between S. Vicente Cape and Lagos Bay contains exposed Mesozoic limestone, and the beaches are generally developed at the river mouths despite their current low sedimentary loads.

Between Lagos and Olhos de Água beach, cliffs are sculpted in Miocene bioclastic limestone and sandstone, except near Albufeira where cliffs are cut into Mesozoic limestone and marls. Eastward from Olhos de Água, cliffs comprise Pliocene and Pleistocene sands. Between Quinta do Lago and Cacela the coastal zone corresponds to the Ria Formosa Barrier Island System with its coastal lagoon (Pilkey et al., 1989).

Karstification on carbonate rocks in the coastal zone occurred at two different times, the older before the Pliocene (paleokarst is buried by Pliocene and Pleistocene clastic sediment), the younger after 40,000 years (Roberts and Plater, 1999). In the Algarve, lithologic units undergo strong tectonics although neotectonic activity produced faults with little vertical throw, and jointing is the most common neotectonic feature. Joints are related with the adaptation of the softer clastic sediments to the vertical karst evolution on the subjacent carbonate rocks (Dias and Cabral, 1998). 


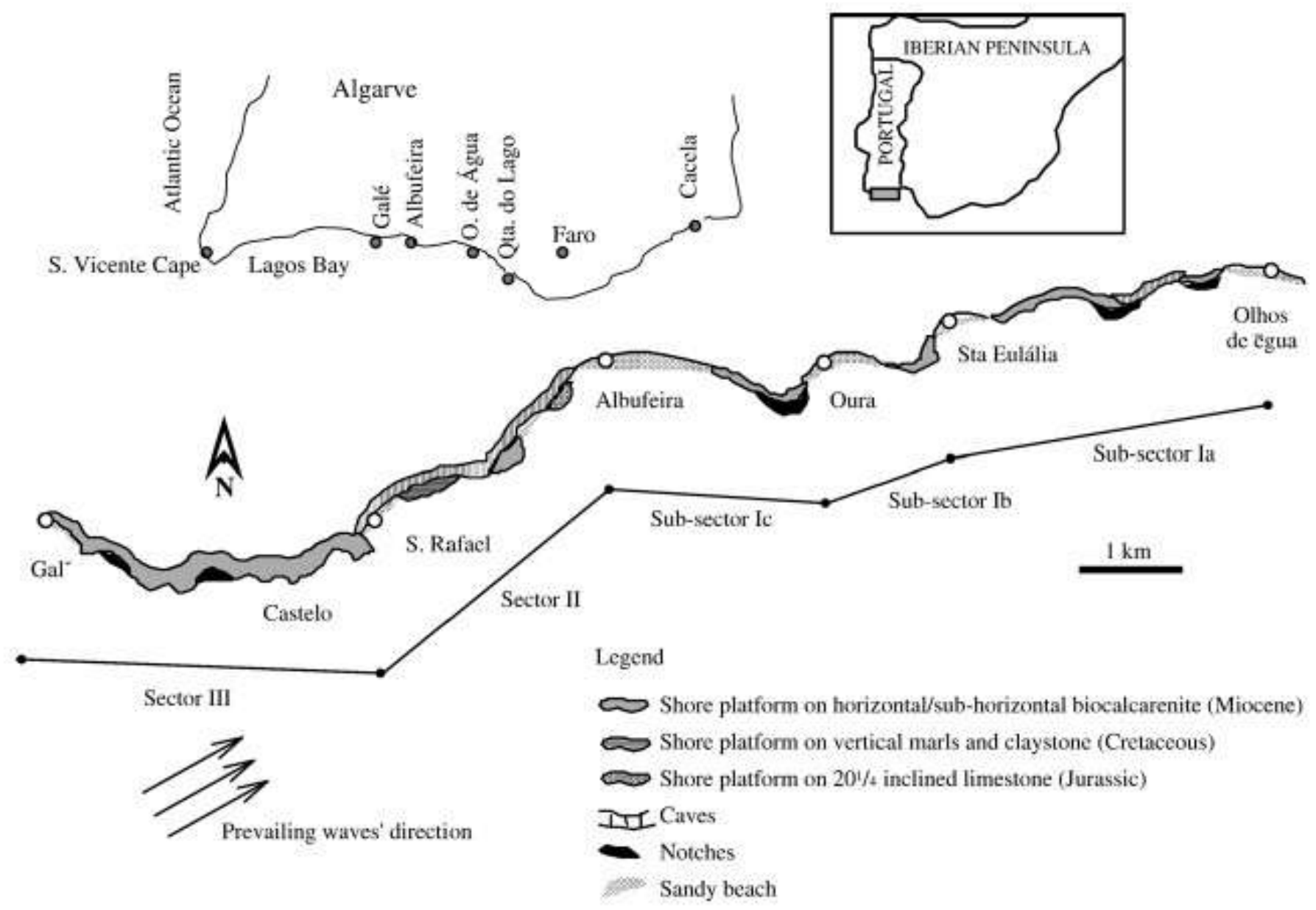

Fig. 1. Location of the study area, the sectors referred in the text as well as the distribution of the most noticeable morphologic features in each sector.

The study area is located in the central part of the south coastal sector between Galé and Olhos de Água beaches (Fig. 1). Large-scale morphologic features characteristic of the study area include: i) step cliffs with at least two different raised shore platforms; ii) merging cliffs; iii) zeta bays; and iv) pocket beaches. The measured wave climate in the area shows that waves approach from the WSW for $90 \%$ of the year on average, and from the ESE during the remaining 10\% (Costa, 1994). Wave height ranges from $0.30 \mathrm{~m}$ to $1.8 \mathrm{~m}$, with rare exceptional heights of more than $3.7 \mathrm{~m}$. Such high waves are associated with storms from the SW, during which waves attain an average 2-3 m height with a period of 7-8 s (Pires and Pessanha, 1979, 1986; Pires, 1989). The tidal regime is semidiurnal and mesotidal with tides ranging from 2.70 to $1.36 \mathrm{~m}$ during neap tides and from 3.82 to $0.64 \mathrm{~m}$ during spring tides measured in the Vilamoura harbour, ca. $30 \mathrm{~km}$ eastward from the study area (data from the Instituto Hidrográfico, 1990). The mean rate of relative sea-level rise is $1.5 \pm 0.2 \mathrm{~mm} / \mathrm{yr}$ according to data from the Lagos tide gauge's series registered between 1908 and 1987 (Dias and Taborda, 1992).
For the purposes of characterizing the coast, the study area was divided into three sectors based on their different geographic orientations which have resulted in contrasting exposure to the prevailing wave direction (Fig. 1). It is this differential exposure to waves that constitutes the principal difference between the studied sectors, because lithology is rather similar, with the exception of S. Rafael-Albufeira sector where cliffs are cut into Mesozoic formations, whilst the remaining stretches of coastal cliffs in the study area are cut into Miocene rocks. However, minor lithological differences may have an influence on coastal morphology, as Marques (1997) found a positive relationship between Miocene rock $\mathrm{CaCO}_{3}$ content and compressive and tensile measures of rock strength.

\section{Methods}

Using 1:25,000 scale topographic maps (Portuguese Military Maps) and aerial photos, a detailed cartography of the shore platforms was made in the field at a scale of $1: 8000$. Shore platforms identified were designated using the letter "P", with P0 being the platform that 
corresponds to the present intertidal zone, and higher numbering (P1, P2) corresponding to the two platforms successively higher than P0. The width, length, and height of each platform were measured using a Real Time Kinematic Differential GPS with a $1 \mathrm{~cm}$ precision. Along the coast several lithostratigraphic columns were produced in order to identify vertical and lateral facies changes and subsequently to correlate them with morphological features. In order to establish the relationship between geological layers and shore platform trends, slope angles were measured with a clinometer. Bathymetric profiles were obtained using the 1:150 000 scale Portuguese Hydrographical Institute bathymetric map and, therefore, the slope values are a rough estimate.

In order to correlate the shore platforms' dimensions and morphologies with heterogeneities in bioerosion/bioprotection, karstification and joint patterns, these aspects were described by field observation. In the study area two lithofacies were characterized based on the rock's compressive strength which increases with increasing $\mathrm{CaCO}_{3}$ content (Marques, 1997): a) fine calcarenite with large fossil shells and strength values from 1 to $3 \mathrm{MPa}$, and b) shelly limestone which strength range from 5 to $15 \mathrm{MPa}$. Accordingly, and considering that rock's resistance and hardness are positively correlated, $\mathrm{CaCO}_{3}$ content is used in the present work as a proxy of rock strength. Carbonate content was determined by sample weight difference before and after $\mathrm{HCl}$ digestion. The residual clastic material was sieved in order to quantify the percentage of clay in the rock. Several pools in the shore platforms' surfaces remain filled by sea water during low tides. In order to evaluate salt saturation during exposure to evaporation conditions, and then the possibility of salt precipitation, salinity in the water pools was measured with a multiparametric probe.

\section{Sector I (Olhos de Água-Albufeira)}

Sector I between Olhos de Água and Albufeira is roughly oriented SW-NE and is, therefore, moderately exposed to the WSW prevailing waves. Prominent headlands with rocky cliffs protect bays with sandy beaches from erosion. In the mainland, the paleorelief of the Miocene rocks has been fossilized by Pliocene and Pleistocene sands. A drainage network, consisting of a few $\mathrm{N}-\mathrm{S}$ rivers incised into the Miocene rocks, is active only during periods of precipitation and yields only a minor sedimentary contribution to the beaches. Considering the lithologic differences along the coast, sector I was subdivided into three sub-sectors (Fig. 1), characterized below. Table 1 summarizes the described coastal morphological features for sector I, as well as for sectors II and III described further below.

\subsection{Sub-sector la (Olhos de Água-Santa Eulália)}

Miocene rocks exposed on the cliffs of this subsector are, upward from the base of the cliffs, calcarenite with large debris shells $\left(\mathrm{CaCO}_{3}=65 \%\right.$; clay $=0.3 \%$ ), laminated medium-grained sandstones, and strongly weathered calcarenites with layers trending $3^{\circ} \mathrm{SW}$ (Fig. 2a). Texture is very heterogeneous because of variations in the mix of coarse grains and in debris shell richness. The intertidal zone develops into either a non-cohesive sandy substratum, or chaotic blocks, or a hard rocky substratum (Fig. $2 a$ ). The locations of both the present shore platform (P0) and the preserved older, higher P1 platform are closely related to the headlands where wave energy is higher.

The platforms reveal a regular system of joints with spacing of about $2 \mathrm{~m}$. Through these joints flows water charged with sand and pebbles during the rising and lowering of tides, carving deep channels into the rock. Platform $\mathrm{PO}$ is a ramp plunging $3-5^{\circ} \mathrm{SW}$, is covered with folious algae, and attains a maximum width of $150 \mathrm{~m}$. In some sites a wave-cut notch 1-2 m high develops into the P0 platform-cliff junction. However, notches are more frequent in areas where the substratum is sand, and in the most sheltered sites where they are removed from direct wave breaking.

The mean height of $\mathrm{P} 1$ shore platform is $4.0 \mathrm{~m}$ and its maximum width is $30 \mathrm{~m}$. This shore platform is horizontal near the cliff junction, but in its seaward section slopes $3-5^{\circ} \mathrm{SW}$ thereby cross-cutting the rock stratification. The P1 platform developed due to the retreat of Miocene and Pliocene cliffs, and thereby it was formed during the Pleistocene. Besides the surface of platform $\mathrm{P} 1$ being rather rough and showing bioerosion traces and karstic holes, some of them containing round pebbles in their floors, it is smoother than the surface of platform P0. During the spring high tide, water splash washes P1 surface, and inside the solution pits water salinity and temperature can rise to 46 and $35^{\circ} \mathrm{C}$, respectively. Along the inner edge of P1 a consistent notch occurs, as well as caves whose floors are covered by pebbles of various lithologies but dominated by calcarenite derived from surrounding geologic formations (Fig. 2b). As a consequence of P1's inclination to the SW, when splash waves erode its southernmost sector during high tide, its landward section is affected only by spray action. Furthermore, 
Table 1

Synthesis of the described morphological features

\begin{tabular}{|c|c|c|c|c|}
\hline Sector & Shore platforms & $\begin{array}{c}\text { Exposure and platform } \\
\text { occurrence }\end{array}$ & Lithology & Shelf slope \\
\hline $\begin{array}{c}\text { Sector I } \\
\text { Sub-sector } \\
\text { la } \\
\text { (Fig. 1) }\end{array}$ & $\begin{array}{lll}\text { P0: ramp } \\
\text { cliff } \\
\begin{array}{l}\text { inner I outer } \\
\text { ledge ledge }\end{array} \\
\end{array}$ & $\begin{array}{l}\frac{\text { Sector exposure to }}{\text { waves }} \\
\text { moderately exposed } \\
\frac{\text { Shore platform }}{\text { occurrence }} \\
\text { headland }\end{array}$ & $\begin{array}{l}\text { - calcarenite and sandstone } \\
\text { - low lithologic diversity } \\
\text { - rock weakness increase upwards } \\
\text { on the cliffs } \\
\text { - layers ranging from horizontal to } \\
3^{\circ} \mathrm{SW}\end{array}$ & depth \\
\hline $\begin{array}{c}\text { Sector I } \\
\text { Sub-sector } \\
\text { Ib } \\
\text { (Fig. 1) }\end{array}$ & 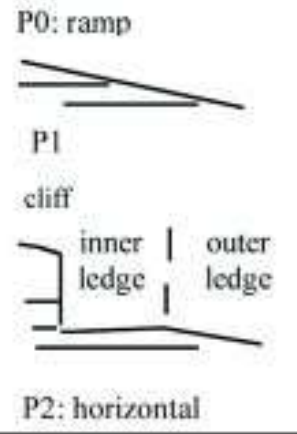 & $\begin{array}{l}\frac{\text { Sector exposure to }}{\text { waves }} \\
\text { moderately exposed } \\
\frac{\text { Shore platform }}{\text { occurrence }} \\
\text { headland }\end{array}$ & $\begin{array}{l}\text { - calcarenite and sandstone } \\
\text { - lateral facies variation } \\
\text { - low lithologic diversity } \\
\text { - texture change laterally } \\
\text { - horizontal layers }\end{array}$ & shoreline \\
\hline $\begin{array}{l}\text { Sector I } \\
\text { Sub-sector } \\
\text { Ic } \\
\text { (Fig. 1) }\end{array}$ & $\begin{array}{l}\text { P0: ramp } \\
\text { eliff } \\
\text { inner I ledge ledge } \\
\end{array}$ & $\begin{array}{l}\frac{\text { Sector exposure to }}{\text { waves }} \\
\text { moderately exposed } \\
\frac{\text { Shore platform }}{\text { occurrence }} \\
\text { headland }\end{array}$ & $\begin{array}{l}\text { - calcarenite and silt } \\
\text { - very low lithologic diversity } \\
\text { - coarse and homogeneous } \\
\text { texture } \\
\text { - horizontal layers }\end{array}$ & (m) \\
\hline $\begin{array}{l}\text { Sector II } \\
\text { (Fig. 1) }\end{array}$ & $\begin{array}{l}\text { P0 on limestone } \\
\text { cliff } \\
\text { PI: horizontal }\end{array}$ & $\begin{array}{l}\frac{\text { Sector exposure to }}{\frac{\text { waves }}{\text { bad exposure }}} \\
\text { Shore platform } \\
\text { hecurtence }\end{array}$ & $\begin{array}{l}\text { - lateral and vertical high } \\
\text { lithologic diversity, as well as } \\
\text { is the texture } \\
\text { - layers range from horizontal } \\
\text { to vertical }\end{array}$ & shoreline \\
\hline $\begin{array}{l}\text { Sector III } \\
\text { (Fig. 1) }\end{array}$ & $\begin{array}{l}\mathrm{P0} \text { : two step platform } \\
\text { P1 wave cut } \\
\text { cliff inner I outer } \\
\text { ledge ledge }\end{array}$ & $\begin{array}{l}\frac{\text { Sector exposure to }}{\text { waves }} \\
\text { well exposed } \\
\frac{\text { Shore platform }}{\text { occurrence }} \\
\text { in all the sector }\end{array}$ & $\begin{array}{l}\text { - high vertical lithologic } \\
\text { diversity but lateral } \\
\text { homogeneity } \\
\text { - layers range from horizontal } \\
\text { to } 15^{\circ} \mathrm{SW}\end{array}$ & shoreline \\
\hline
\end{tabular}



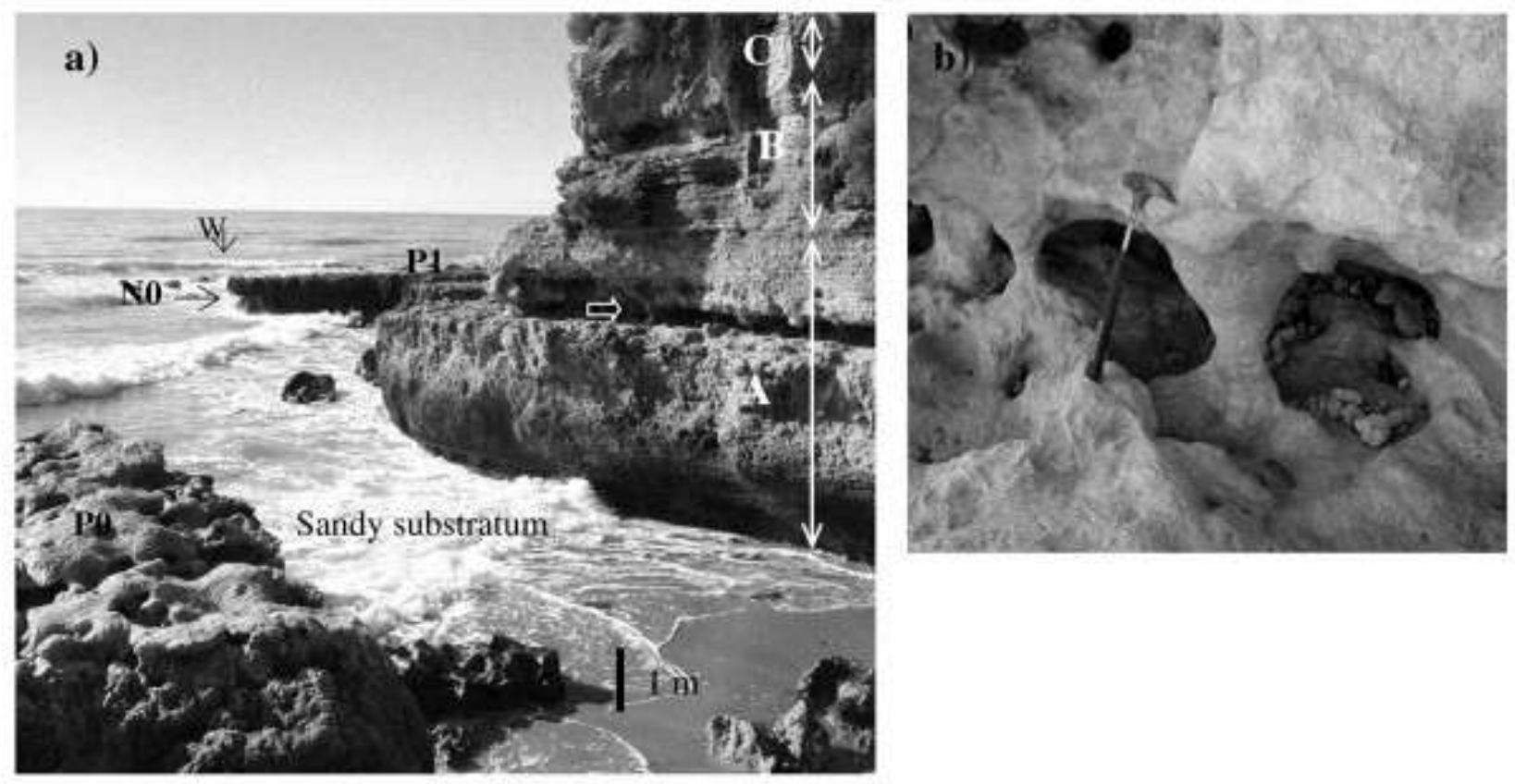

Fig. 2. Photographs of sub-sector 1a during high tide: a) Westernmost sector of the Olhos de Água beach (see Fig. 1 for location), b) close-up of the cave arrowed in photo a) showing pebbles in its floor. a: N0 - notch; P0 - current platform; P1 — shore platform above the present intertidal zone; $\mathrm{w}$ - wave direction before it refracts against the cliffs. Lithology: A - fossiliferous calcarenite, B - sandstone, $\mathrm{C}-\mathrm{calcarenite.}$

the present wave-cut notch shows differential vertical offset from platform P1, from $1.0 \mathrm{~m}$ in the seaward section of $\mathrm{P} 1$ to $3.0 \mathrm{~m}$ in the higher landward section. In interpreting the evolution of such older shore platforms under present mean sea-level conditions, it should be noted that diachronic evolution can occur as a result of platform gradient.

In the more sheltered sites where wave energy dissipates, sandy beaches are developed and caves are frequent at the cliff foot (Figs. 1 and 3). The offshore shelf slope in this sub-sector is gentle, ranging from $0.3-0.5 \%$ (Table 1).

\subsection{Sub-sector Ib: Santa Eulália-Oura}

Three sedimentary bodies with erosive contacts are exposed in the cliffs of sub-sector lb (Fig 1). The cliff's lowermost portion is a $3 \mathrm{~m}$ thick layer with lateral facies variation ranging from strongly cemented massive sandstones ( $\mathrm{CaCO}_{3}<40 \% ; 2.8 \%$ clay) to upper tidal sandy facies with thin laminations including heavy mineral horizons. Overlying these sandstones there is a $3 \mathrm{~m}$ massive biocalcarenite layer, which has a very irregular texture due in part to the large mollusk and echinoderm fossils. Pliocene and Pleistocene red sands
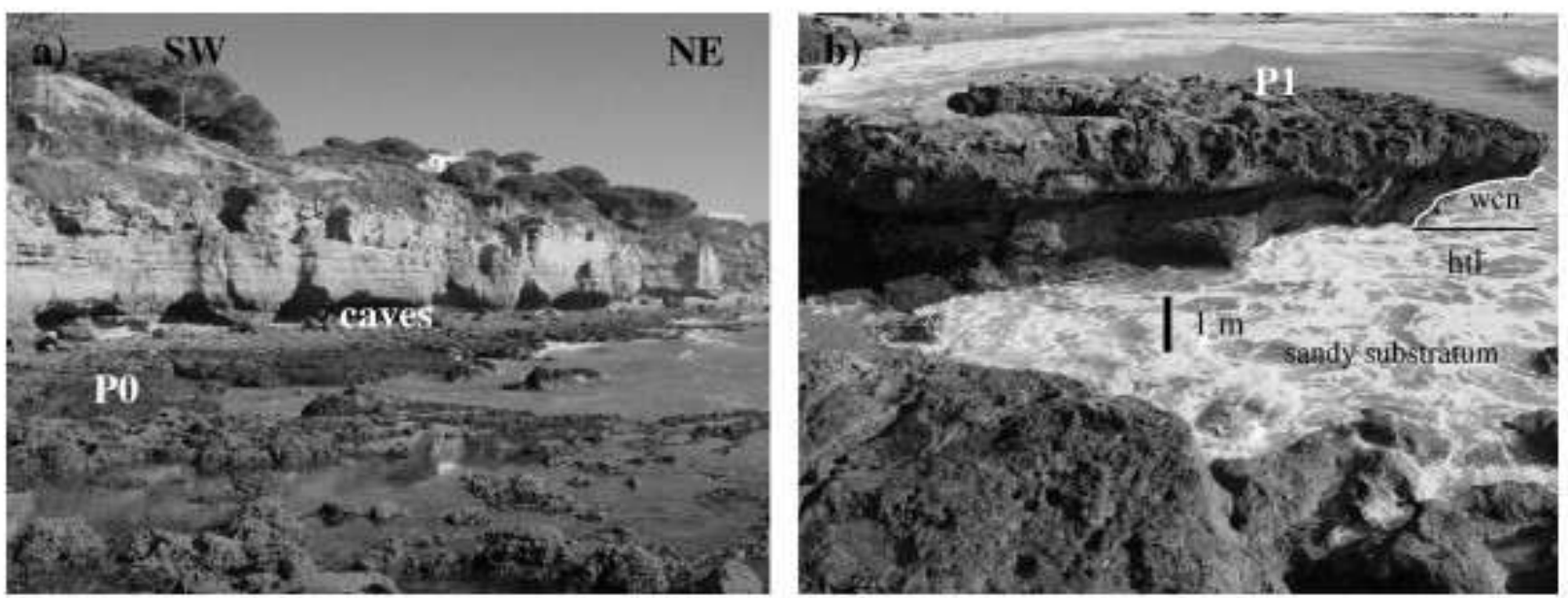

Fig. 3. Some features of coastal sub-sector la (see Fig. 1 for location): a) Low tide, SW-NE with marine cave; b) high tide, westward of site showed in a): wcn — wave cut notch, htl — high tide line. 
constitute the cliff's upper portion where its profile is sloping and slightly concave in contrast to the vertical profile exhibited by the carbonated layers.

Three platforms are preserved in this sub-sector and, as in sub-sector la, the present platform and the higher ones exhibit close geographic correspondence, i.e. P1 and P2 occur where P0 is developed. These sets of platforms are confined to the headlands that contain Santa Eulália Bay. Although the width and length of platform P1 in some sites measure no more than $2 \mathrm{~m}$, in the westernmost part of Santa Eulália beach it shows a width of up to $30 \mathrm{~m}$. The morphological pattern of shore platform P1 is similar to that in sub-sector la, being horizontal close to the cliff junction and trending $3^{\circ} \mathrm{SW}$ in its seaward section down the line of the wave splash influence (Fig. 4a). Furthermore, there is a consistent alignment of caves along the level of the cliff-platform junction. The P1 discontinuity in the eastern exposure is probably due to platform collapse in some sectors caused by notch development at the base of the cliff favouring its rapid retreat by rock fall. A third platform, P2 (Fig. 4b), is developed at the contact between calcarenite and the Pliocene sand. P2 does not exceed $15 \mathrm{~m}$ wide and is $8-10 \mathrm{~m}$ high. On this platform surface, karstic holes have developed, some of them being filled by silt and clay derived from limestone weathering. The offshore slope in this sub-sector is a gentle one ranging from 0.2 to $1.0 \%$ (Table 1 ).

\subsection{Sub-sector Ic: Oura-Albufeira}

Between Oura and Albufeira beaches, shore platforms occur in the easternmost part of the sub-sector (Figs. 1 and 5). This sub-sector is lithologically more homogeneous than the other sub-sectors, being composed of a fossiliferous calcarenite $\left(\mathrm{CaCO}_{3}=72 \%\right)$ with coarse texture in the lowermost part of the cliffs (layer A) and by clastic formations (layers B and C) in the top portion of the cliffs (Fig. 5a). There are two shore platforms: P0 cut into layer A, and a higher platform P1
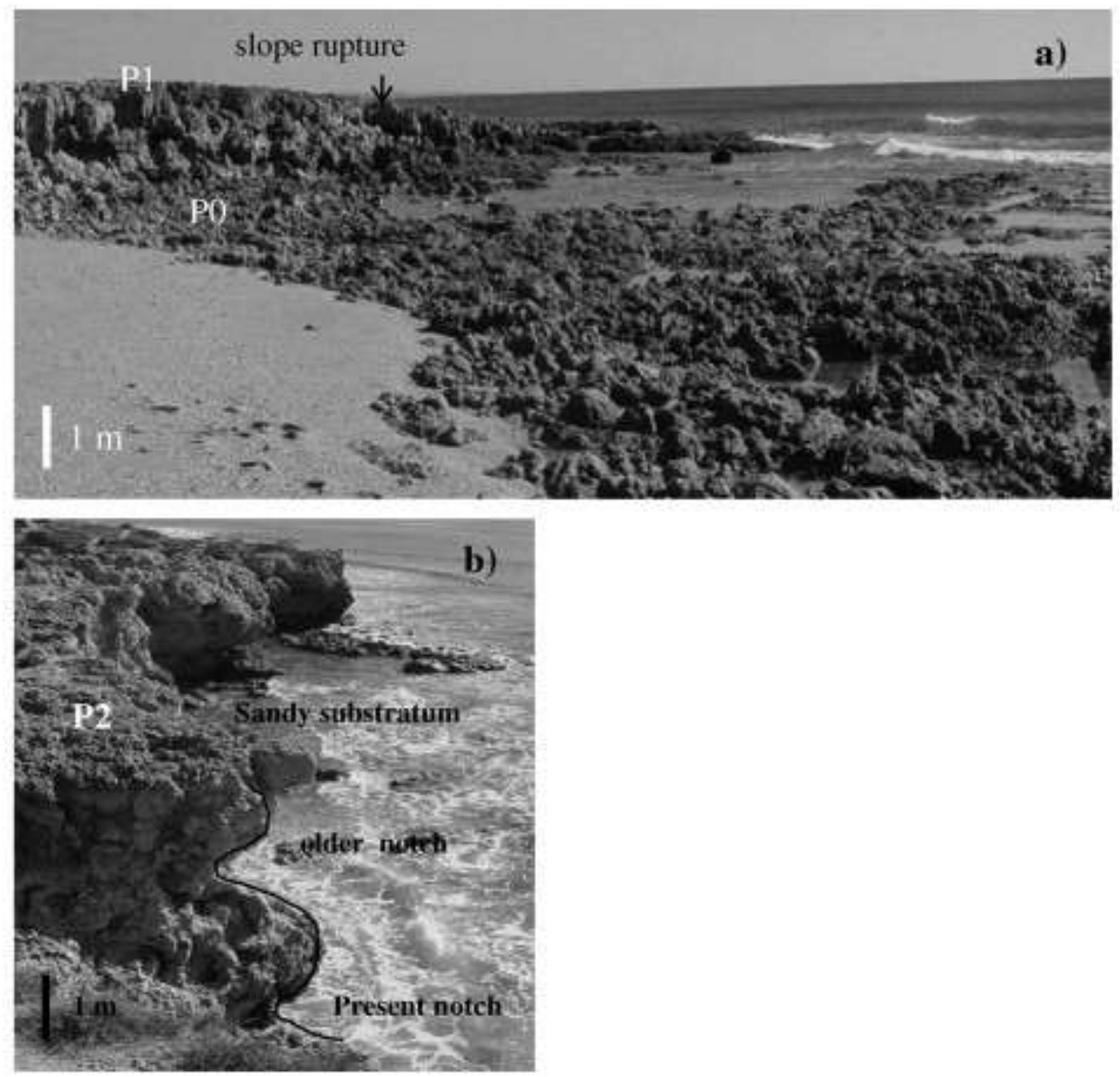

Fig. 4. Morphologic features in sub-sector lb (see Fig. 1 for location): a) spatial relation between P0 and P1 platforms. Whilst the outer portion of P1 platform is reached by waves during the high tide, its inner part is $2 \mathrm{~m}$ higher than the present intertidal platform P0; b) platform P2 and a notch above the intertidal zone. 

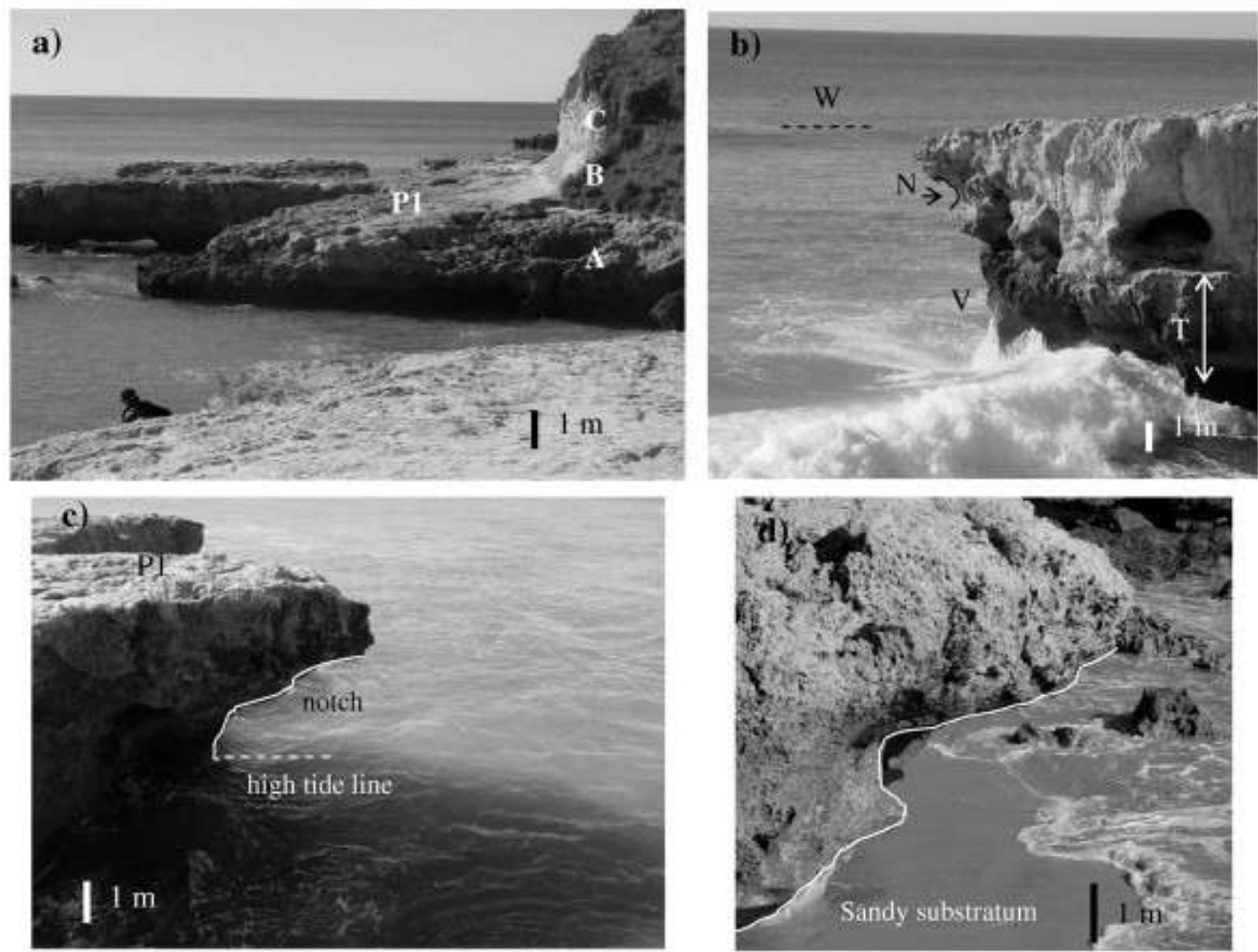

Fig. 5. Some morphologic features in sub-sector Ic (see Fig. 1 for location): a) P1 platform, b) Platform P2 and an older notch, c) and d) notches with roofs above the high tide line. Lithology in Fig. 2a): A - bioclastic calcarenite, B - siltstone, C - conglomerate (note that P1 is cut into the A-B layer contact). Fig 2b): $\mathrm{W}$ - wave crest before it refracts against the cliff, $\mathrm{N}$ - notch, $\mathrm{V}$ - vertical wall after rock fall, $\mathrm{T}$ - zone of wetting and drying processes.

that is horizontal in its landward section and slopes $3^{\circ}$ SW seaward (Fig. 5a). The surface of P1 is strongly karstified with holes through which sea water ascends during high tides and washes the surface of the platform. This sub-sector is distinguished from sub-sectors la and lb by the laterally consistent set of notches, formed at various heights with roofs above the high tide line (Fig. $5 b, c, d)$. The adjacent continental shelf suddenly shoals close to $1550 \mathrm{~m}$ from the shore with a slope break from $0.2 \%$ to $1.2 \%$ (Table 1 ).

\section{Sector II: Albufeira-S. Rafael}

This sector, with its shoreline oriented SW-NE and subparallel to the prevailing wave direction (from the WSW), is straighter than sector I and has a main headland protecting Albufeira Bay (Fig. 1). Cliffs are retreating rapidly in this sector, and in some parts the intertidal zone is now developing on the debris resulting from rock fall from the cliffs. The drainage network is poorly developed, characterized by short rivers oriented $\mathrm{N}-\mathrm{S}$.

Lithologically, this sector is quite different from sector I, the cliffs being cut from northeast to southwest into Jurassic limestones sloping $20^{\circ} \mathrm{S}$, vertical Cretaceous marls, and horizontal Miocene calcarenites. Near S. Rafael, where interlayered vertical marls and claystones are exposed, a horizontal P0 platform cuts the stratification. The platform surface is very irregular due to differential erosion, and achieves a maximum width of $150 \mathrm{~m}$. Notches are absent where the Cretaceous marls are exposed, but several deep caves are carved into the layers' contacts. Fragments of a P1 platform $3 \mathrm{~m}$ high, and no more than $3 \mathrm{~m}$ wide, intersect the limestone stratification. Where it cuts the Cretaceous layers, P1 is $5 \mathrm{~m}$ high and contains vertical karstic holes with polished walls (Fig. 6). In this sector, a third platform P2, measuring some $8 \mathrm{~m}$ in height and from 3 to $15 \mathrm{~m}$ in width, is developed in the Miocene calcarenites. The offshore 

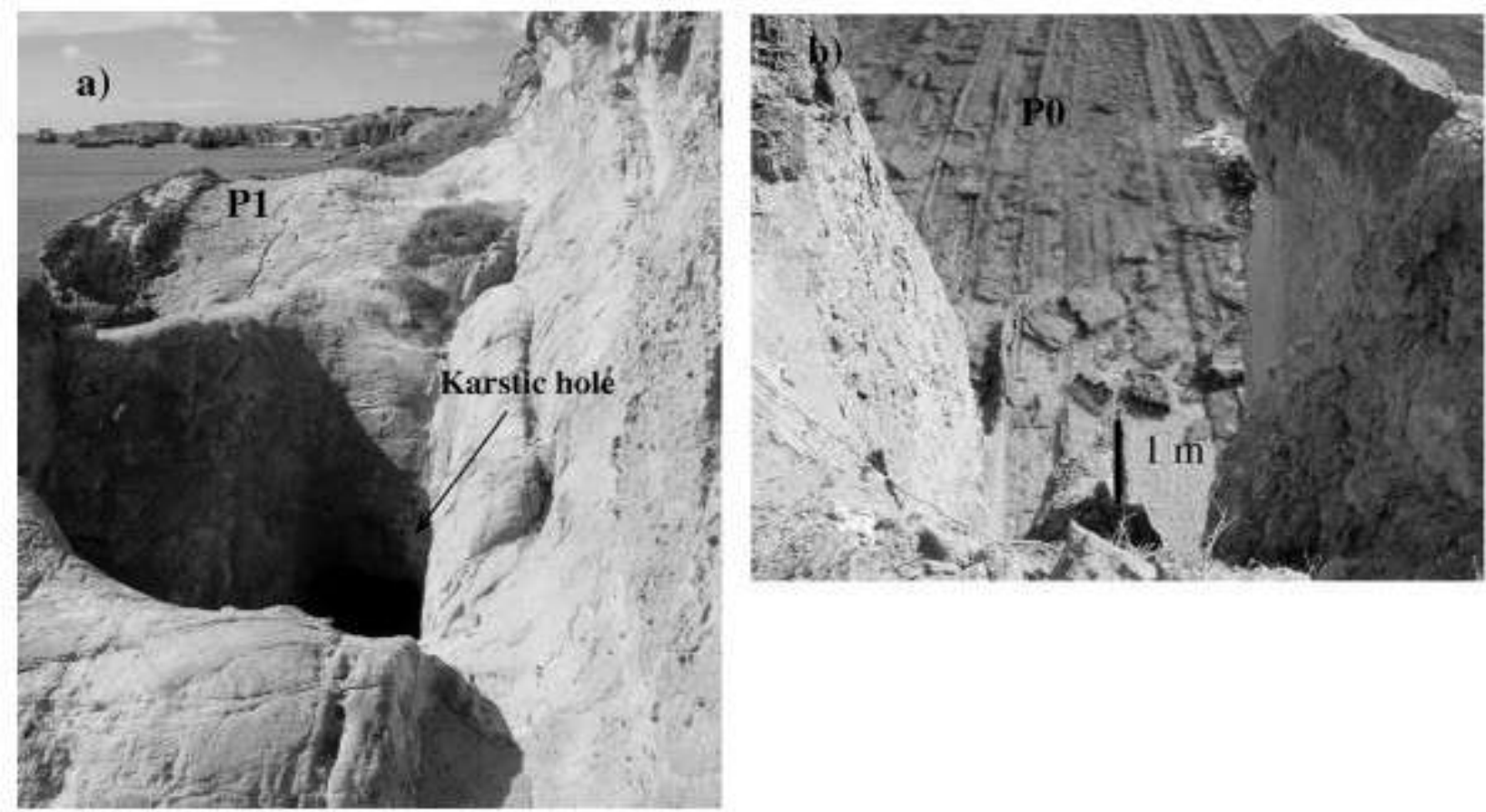

Fig. 6. Morphological features of sector II (see Fig. 1 for location): a) P1 developed into the vertical layers; b) P0 cutting vertical marls and claystones from the Cretaceous.

slope in sector II changes abruptly from 0.5 to $1.3 \%$ $750 \mathrm{~m}$ from the shore (Table 1).

\section{Sector III: S. Rafael-Galé}

The coastline of sector III (Fig. 1) is oriented W-E, and it is a very irregular coastal sector with pocket beaches. This sector exhibits greater vertical facies variation than the other sectors, with cliff rocks comprising a sequence of fossiliferous Miocene calcar- enites and cemented siltstones. Exposures contain layers that are rarely thicker than $1 \mathrm{~m}$ with dips ranging from horizontal to $10^{\circ} \mathrm{SW}$. The present shore platform P0 is characterized by two distinct sections. Whereas the seaward section dips $3-5^{\circ} \mathrm{SW}$, and is quite smooth and covered by algae, the landward section by comparison is horizontal and rough (Fig. 7). Continuity in the seaward section is interrupted by holes carved by echinoderms which produce potholes with diameters of up to $50 \mathrm{~cm}$ when collapsed. The landward section of PO is

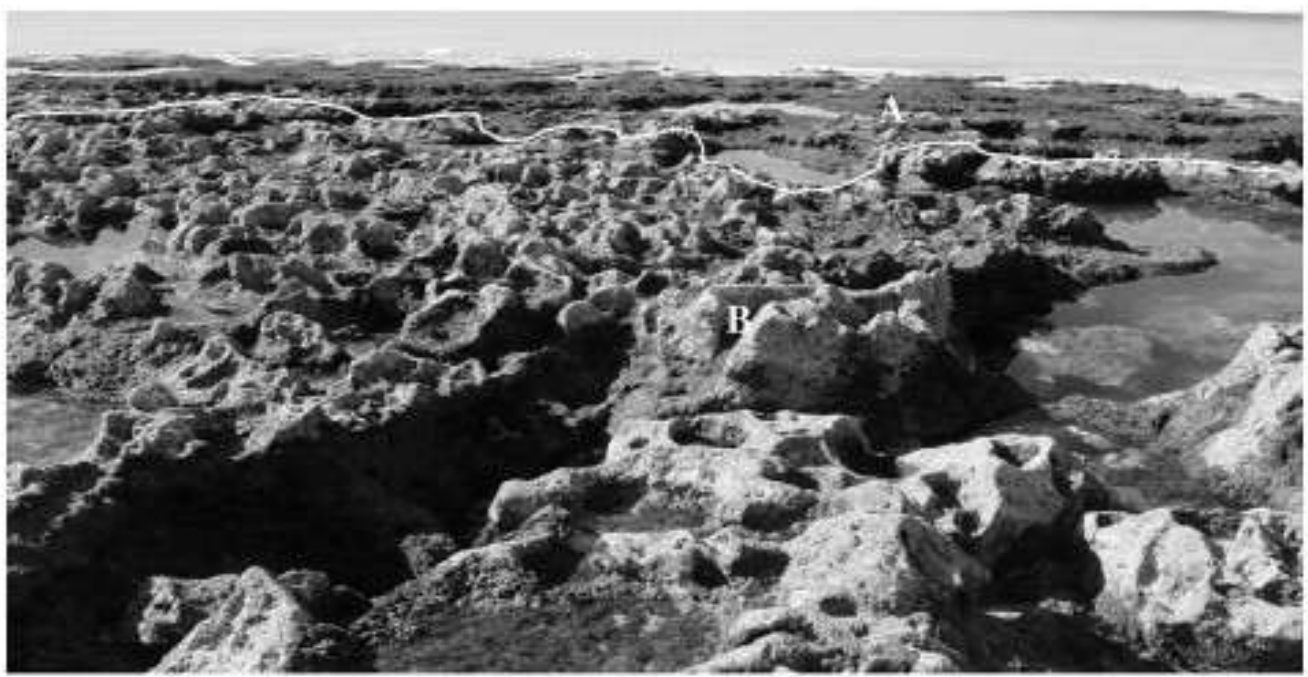

Fig. 7. Morphological features of present platform P0 at the Galé site (see Fig. 1 for location). Differences between the algae (A) and Balanidae (B) domains. 
colonized mainly by Balanidae that protect the rocks from wave erosion. Moreover, in the landward section, rocks are affected by two orthogonal directions of joints conferring a channel-mound (joint-sector protected by shells) aspect to the platform surface, due to differential erosion. A wave cut in the P0/P1 junction and a notch in the most sheltered sectors where the substratum is sand also occur in this sector.

Platform P1 is well preserved and shows notable lateral continuity, and has a mean height of $5 \mathrm{~m}$ and a maximum width of $80 \mathrm{~m}$. As a consequence of P1's trend $\left(3^{\circ}-5^{\circ}\right.$ to SW), during high tides the southernmost (seaward) section receives wave action whereas its landward section receives only wave splash. The landward section of P1 exhibits surface irregularities, and close to the cliff junction salt crystals have formed. A third platform (P2) is cut into the Miocene formation, although its lateral continuity has been lost by the intense karstification of the carbonated rocks. The adjacent offshore shelf shows a pronounced step at $750 \mathrm{~m}$ from land with a 1.3\% slope (Table 1).

\section{Discussion}

Shore platforms, notches and marine caves are common yet distinctive morphological features along the southern coast of Portugal. The central Algarve rocky coast has provided a favourable setting in which to understand the processes contributing to shore platform development. This is because the morphology and characteristics of the features vary along the coast, as do several factors implicated in their development such as wave climate (including wave direction and frequency), seabed morphology and depth, bedrock lithology, karstification and geological structure.

As already stated, karstification is a common feature in the studied coastal sector and acts on shore platform evolution at several levels: first, the occurrence of solution pits (Wentworth, 1944) contributes to the platform's surface irregularity; secondly, karstic holes through which sea water ascends during high tides and washes the surface of the platform contribute to the increase of the P1 platform width. This latter process is particularly active in the sector Ic (Oura-Albufeira) where the washing effect erodes the softer sediments overlying the platform (Fig. 5a); thirdly, the collapse of the karstic galleries is probably the main factor controlling the retreat rate of the rocky cliffs in the studied area that is globally low, 0.01$0.08 \mathrm{~m} / \mathrm{yr}$, and even lower in the headlands where wave energy dissipates against the shore platforms (Marques, 1997).
Joints are a structural feature that affects the overall sector, and like karstification influences the shore platform's roughness and width. Joints allow easier water percolation, deepening channels through which sea water can reach the inner parts of the platforms that become very discontinuous. Furthermore, joints increase the instability of the seaward platform ledge, and when a notch develops in the P0-P1 junction this part of the platform can fall, reducing thus the platform width.

Karstification and joints do not only contribute to the rock weakness but they also act as resistant points to erosion as their walls are frequently indurated by carbonate precipitation becoming in such case more resistant than the adjacent rocks (Marques, 1997).

7.1. Intertidal zone shore platform: factors controlling platform development and morphology

The present shore platform (P0) in the Algarve study area develops in several substrata such as calcarenite with heterogeneous fabric, limestone and marls, as well as in different structural layers ranging from horizontal to vertical joints and layers. Several processes have been identified in the literature as being responsible for shore platform generation, such as wave erosion, abrasion, chemical weathering and biological weathering (Bartrum, 1916; Johnson, 1919; Wentworth, 1938; Bird and Dent, 1966; Trenhaile, 1987, 2000; Stephenson and Kirk, 2000a,b; Trenhaile, 2001a,b; Stephenson and Kirk, 2001; Trenhaile, 2002a,b; Andrade et al., 2002; Twidale et al., 2005), but it is not clear which of these processes assume the greatest importance. This difficulty is probably due to the observation that shore platforms develop in very diverse geomorphologic, geologic, oceanographic, climatic and biologic contexts, and therefore the first-order factors responsible for shore platforms probably vary according to the macroenvironment in which they form.

Stephenson and Kirk (2000a) measured several parameters related to wave erosion on shore platforms, including breaking waves, wave energy flux from deep water, onshore wave energy flux and shear stresses under waves. They concluded that breaking waves and hydraulic forces are not responsible for the development of the Kaikoura platforms in New Zealand. However, a well-developed present platform in the Algarve study area is closely associated with the more exposed sectors of coast and with the headlands in the moderately exposed sectors where wave energy is higher (Komar, 1998), suggesting that wave energy is relevant to shore platform sculpture in this area. Wave break point depends on the floor slope and is located where wave 
shoaling occurs (Short, 1999; Noormets et al., 2004). In the areas of coastline in the Algarve where the intertidal zone corresponds to a platform, the wave break point occurs before waves reach the platform; in which case waves undergo refraction. In this situation, the platform corresponds to the surf zone characterized by highfrequency turbulence and incident and infragravity wave motion, representing a significant amount of wave energy causing shear stress (Short, 1999; Costa et al., 2002). The presence of wave cuts into the $P 0$ and $P 1$ platforms junction testifies that wave energy acting on the platform during rising tides is sufficient to erode a landward ledge.

When the shelf slopes are compared (Table 1), they are steeper westward with a positive correlation with shore platform extension, although this does not necessarily imply a direct cause-effect relationship. Headlands exist when shoaling occurs and wave energy is concentrated in these prominent coastal sites (Komar, 1998), displacing the positive relationship to that between wave climate and shore platform sculpting processes. Moreover, a steeper slope results in a slower shoreline migration (Emery and Uchupi, 1972; Sanders and Kumar, 1975; Bender and Dean, 2004) and, during a still-stand in sea level, waves act on a platform for a longer time than in sites of gentler slopes. In their model, Inman et al. (2003) used a $2 \%$ continental shelf slope (similar to the slope in sectors II and III) with a rapid rise in sea level interrupted by a still-stand, and obtained a shelf slope recedence of $15 \mathrm{~m}$ during the rapid rise of sea level and a wave-cut terrace $100 \mathrm{~m}$ wide during a simulated 1000-year duration still-stand. In the Algarve, sea level rose about $80 \mathrm{~cm} / 1000$ yrs between 8000 and $6000 \mathrm{yr} \mathrm{BP}$, reducing to $30 \mathrm{~cm} / 1000 \mathrm{yrs}$ until around $3000 \mathrm{yr}$ BP when it was very close to the present level (Pereira et al., 1993; Boski et al., 2002; Teixeira and Pinto, 2002a). Therefore, comparing these values with those obtained by Inman et al. (2003), P0 platform (up to $150 \mathrm{~m}$ wide) could be scraped and smoothed mainly by wave erosion during the last ca. $3000 \mathrm{yr}$. Moreover, in the vicinity (30 km eastward) Teixeira and Pinto (2002b) estimated a shoreline retreat of ca. $30 \mathrm{~cm} / \mathrm{yr}$ for the same time interval.

The water hammer (or shock pressure) effect has been identified as an important process in the mechanics of wave erosion (Bagnold, 1939; Havelock, 1940; Sunamura, 1975; Trenhaile, 2000). However, shock pressure requires a vertical wave front that must rise at some distance before breaking onto the cliff (Noormets et al., 2004). The sites where the P0 shore platform occurs are reached by broken waves without significant vertical elevation. Therefore, water hammer must have, at best, a modest contribution on sculpting platforms.

Abrasion occurs when sand or pebbles are transported by water (Kershaw and Guo, 2001), but bedrock wave cutting occurs in the absence (or near-absence) of sediment cover (Inman et al., 2003). In the study area, coarse sand grains and round pebbles accumulate in the holes' floor and cracks and are used as tools to abrade under the turbulent water motion. Therefore, although waves do not break directly onto the P0 platform, waves have an important role in sculpting it due to the energetic, high-frequency breaking and infragravity waves, as well as their capacity to carry abrading sediments. The platform's gentle WSW slope (corresponding to the direction of prevailing incident waves), which cuts the rock stratification, and the confinement of the platform's development to the well-exposed sites, point to wave action as the principal mechanism forming the present shore platform along the Algarve coast.

Some investigations have shown weathering processes to be important in platform development. For example, Stephenson and Kirk (2000b) identified salt weathering, water layer weathering, and repeated wetting and drying as the main factors in the development of shore platforms near Kaikoura, New Zealand. In the Algarve, however, the tidal regime is semidiurnal, meaning that the present shore platform is submerged too often to allow salt crystallization to be significant. Salinity in water pools never exceeds seawater concentrations, and no salt crystals were observed in the walls of pools exposed during low tide. Beside the heterogeneity of the fabric of the calcarenite, the clay content is also very low $(<3 \%)$. Repeated wetting and drying essentially affect only those rocks with high clay contents, and therefore would not affect the Algarve platform, with the possible exception of the marls exposed in S. Rafael.

Dissolution is a very important weathering process in carbonated rocks, mostly in $\mathrm{CaCO}_{3}$ undersaturated environments. In addition to the present aridity in the Algarve, the salinity in coastal waters declines during the wetter winters, due to continental water input. Under these conditions, minor carbonate dissolution can occur, and well-preserved ornamentation in fossil shells is apparent in some sheltered sites. Platform P0 presents two different sections in the S. Rafael-Galé sector, with fixed organisms probably responsible for the two-step profile. In its seaward section, foliose algae protect rock from erosion and the platform surface that plunges seaward is quite smooth, being indented only by echinoderm holes that contribute to bedrock erosion. The protective effect of algae, as well as a positive 
relationship between exposure and biocolonization, has previously been observed by Naylor and Viles (2002) and Carter and Viles (2005). The landward section of the platform is horizontal and it surface is very irregular because of the differential erosion between the jointed units (through which water preferentially flows) and the areas protected by Balanidae shells. Bioerosion and bioprotection (Naylor and Viles, 2002), therefore, are processes that contribute to platform erosion and morphology in the Algarve.

Various other factors potentially control shore platform dimensions, morphology and slope. The widest and most continuous platform occurs in the subhorizontal calcarenite layers in the well-exposed sections of coastline in sector III, whereas the smallest width was observed cut into the Jurassic limestones in sub-sector Ic (Fig. 1). Trenhaile (2002a) found that marine platform width is negatively related to rock strength. However, this relation does not appear to hold on the Algarve coast, because the width of the platform developed on the Cretaceous interlayered marls and claystones is the same as that developed in some sections of the cemented Miocene calcarenites. Moreover, platform width varies from one site to another where it developed on the same bedrock. Structure, however, does seem to control platform width. Platform width is greater when developed on stratified sedimentary rocks such as in S. Rafael (vertical layers) and in Galé (sub-horizontal layers) than when developed on massive bedrock, such as in the whole of sector I (Fig. 1). It is likely that such structural discontinuities act as planes of weakness favouring erosion by water percolation.

The developing shore platform along the Algarve coast ranges in slope from horizontal to $3^{\circ} \mathrm{SW}$, which is in good agreement with Trenhaile's (2002a,b) experiments that indicate a direct relation between platform slope and tidal range. Moreover, for mesotidal regimes which is applied to the Algarve, abrasion platforms should slope gently or be horizontal.

The present platform develops in different geologic contexts (Table 1), the common factor being the degree of exposure to waves. We conclude that whilst wave attack is the first-order factor controlling the development of the platform, other factors, such as lithology, structure, chemical weathering and bioerosion/bioprotection, are responsible for its morphological features. they are in equilibrium with the present sea level (i.e. actively forming) or whether they were formed when relative sea level was higher. Although this question has been investigated with respect to several rocky coasts (e.g. Dickson and Woodroffe, 2002), it is clear that differentiating the processes relevant to different platforms in the same area remains a challenging problem.

P1 ranges in width from $3 \mathrm{~m}$ to $80 \mathrm{~m}$, being vestigial in sub-sector Ib and sector II, and showing a remarkable lateral continuity in the well-exposed sector III (Fig. 1). The close geographic correspondence between platforms P0 and P1 can be explained in two possible ways: a) P1 is an older abrasion platform corresponding to a sea level higher than the present, therefore implying that the corresponding coastal morphology was very similar to the present one; or b) P1 is in equilibrium with present sea level and has formed as the result of sub-aerial weathering processes. Several arguments favour the first hypothesis: including the presence at the P1/cliff junction of notches and caves containing rounded pebbles; the seaward slope of P1; bioerosion traces in the platform surface; and the height (3-5 $\mathrm{m}$ above mean sea level) and width of P1 which preclude wave erosion affecting the platform even during spring tides. In addition, although storm surge is a potential factor to consider in the development of platforms higher than the tidal range, it can be disregarded in the evolution of platform P1 because the significant storm surge in the Algarve area is only $33 \mathrm{~cm}$ in magnitude (Gama et al., 1994). However, in some sites as described above in the results and discussion, joints and karstic holes allow sea water to reach the inner portions of the platform, and water content is therefore locally increased. The rock resistance decreases as the water content increases (Marques, 1997; Kanyaya and Trenhaile, 2005), and the portions of platform reached by sea water become thus softer and more vulnerable to granular disintegration contributing to reduce the platform wide.

With the exception of sector III, where there is a ramp, P1 is horizontal close to the platform-cliff junction and plunges seaward in its seaward section. In sector III, a consistent notch and several caves occur at the P1/cliff junction, but the notch appears to be structural in origin, being developed in a weak siltstone layer. In addition, in sub-sector Ic, the platform surface is affected by karstic holes communicating with the supratidal zone, and through which water ascends when waves break and splash causing erosion of the underling weak siltstone. In the more protected sites, several notches and caves at the same height as the P1 landward ledge are developed in a single layer, pointing to a wave abrasion origin. According to our observations,

\subsection{Shore platforms above the intertidal zone}

Platforms (P1 and P2) lying above the present platform occur at the headlands of all studied sectors. A key question concerning these platforms is whether 
therefore, platform P1 must be an older platform inherited from former environments, but which is now undergoing chemical weathering and differential erosion because of vertical lithologic heterogeneity.

Platform P2, with a mean height of $8 \mathrm{~m}$, is discontinuous and is variable in width. Its discontinuous character is due to the strong karstification developed into the bedrock which in some areas has masked the platform. Three scenarios for the development of this platform are possible: a) karst development after the platform's formation by sea erosion; b) a platform developed on a previously irregular karstic topography; or c) an exhumed Miocene karstified surface. Based on U-Th series disequilibrium data, Roberts and Plater (1999) suggest ages younger than 40,000 years for the mechanical and chemical weathering of the Miocene calcarenite, which excludes scenario (c). Moreover, between $67 \mathrm{ka}$ and $16 \mathrm{ka}$, the Portuguese margin experienced the Last Glacial comprising Marine Isotopic Stages (MIS) 4-2 (Abreu et al., 2003), during which the mean sea level was much lower than at present. Therefore, the calcarenite karstification must have occurred after the development of platform P2 during a previous sea-level highstand.

\subsection{Notches and marine caves}

\subsubsection{Notches}

Marine notches occur consistently in sector I, mostly where the substratum is sandy, and they can be divided into four morphological types: 1) u- or v-shaped notches whose roofs and floors are symmetrical with respect to the retreating point; 2) w-shaped notches where the roof is deeper cut than the floor; 3 ) ripple notches (Pirazzoli, 1986); and 4) two-step notches, the upper step being a surf notch. It is difficult to find common factors between each group as well as factors determining their differences, because each type occurs in different exposure and lithologic contexts. Nevertheless, symmetric u- or v-shaped notches occur mainly in cliffs in sheltered sites where wave attack occurs after refraction with minor splash effect. Accordingly, the notch roof corresponds to the high tide line, making it a reasonable proxy for sea level as noted by Pirazzoli (1986). With respect to the $u$ - or v-shape, we observed that the former usually occurs when the substratum is a non-cohesive medium sand whilst the latter form when they lie above a rocky platform, probably due to the lack of sand abrasion action.

In the studied area, w-shaped and ripple notches are the more common types, and according to Pirazzoli (1986) they are usually associated with coastal emer- gence lower than the tidal range. In sub-sector la (Fig. 1), only w-shaped and ripple notches occur, whereas in sub-sector lb u- and v-shaped notches occur laterally to w-notches and ripple notches, meaning that other factors, such as bioerosion and differential erosion due to lithologic variation, must influence their morphology. However, further investigation is needed to more fully understand the relevant factors operating on notch development. In the far west of sector I (Fig. 1) where waves break directly against the cliffs into a noncohesive sand substratum, a two-step notch has developed; the upper notch with roof $3 \mathrm{~m}$ above the high tide mark being cut by the energetic wave splash.

In sector II between Albufeira and S. Rafael, characterized by Jurassic limestones plunging $20^{\circ}$ seaward and vertical Cretaceous layers, notches do not occur. Several factors, such as lithology, the dip and direction of layers, and cliff retreat, could potentially explain this. Sector II is the sector least exposed to the prevailing waves, but, in sectors I and III, notches occur on both the exposed and sheltered sites, corroborating the lithologic and structural controls on notch generation.

In sector III (S. Rafael-Galé, Fig. 1), notches are mostly u- or v-shaped, and despite this sector being the most exposed to incident waves, there are no surf notches. As discussed, this is because the shore platform is reached only by broken waves. Notch generation is independent of the degree of exposure, but requires a clastic environment which in turn controls notch morphology.

\subsection{Caves}

Marine caves develop in the Algarve in several lithologic and structural contexts, in two distinct situations: a) at the sheltered cliff foot reached by refracted waves, and $b$ ) at the foot of the plunging cliffs under the direct break of waves. Geological features that alternately contain air and water, such as joints, bedding contacts, karstic holes and pores, are under hydrostatic and shock pressure; a condition that promotes rock erosion in coastal areas (Stephenson and Kirk, 2000a; Trenhaile, 2002a; Noormets et al., 2004). Whilst the occurrence of caves at the base of the well-exposed plunging cliffs can be explained by shock and hydrostatic pressures, other processes must be operating in the more sheltered sites. In such sites, rocks support dry conditions for longer, allowing salt to precipitate and contribute to rock weathering. Salt weathering and karstification in combination with shock pressure generated during storms, when the more energetic 
waves reach the base of the cliff, could explain cave formation by rock collapse.

\section{Conclusion}

In the Algarve south coast, the occurrence of shore platforms is closely tied to exposure to the prevailing wave direction. Wave attack is, therefore, the first-order factor on sculpting shore platforms, whereas platform dimensions are influenced by the degree of wave exposure and by the lithology and structural trend of geological layers. Smaller-scale morphological variations are caused by chemical weathering, bioerosion, and bioprotection.

Shore platforms lying above the present tidal range are inherited from older sea-level highstands. These platforms are currently undergoing differential subaerial weathering in sympathy with local lithologic variations. Karstic features and joints contribute to the roughness and discontinuity of the platforms' surface. They can promote both reduced and increased platform width by means of water percolation, particularly at the cliff-platform junction. Wide platforms occur when the platform is formed at the contact between calcarenite and softer sediments, and when sea water washes the surface several times a year. Narrow platforms are due to rock fall or granular disintegration; both processes are favoured by karst and joint discontinuities.

Notch occurrence in the study area is independent of the degree of exposure but mostly occurs in sandy substrata, and their morphologies suggest coastal uplift of some sectors. The principal processes responsible for cave formation are shock and hydrostatic pressure, as well as chemical weathering in the more sheltered sites.

\section{Acknowledgements}

The research was supported by $\mathrm{COCHAL}$ Project (POCTI/34162/CTA/00), funded by the Portuguese Foundation of Science and Technology, FEDER and $\mathrm{OE}$. We would like to thank reviewers for their comments that greatly improved the manuscript.
Portuguese west coast. In: EUROCOAST (Ed.), Littoral 2002. The Changing Coast, Porto, pp. 423-431.

Bagnold, R.A., 1939. Committee on wave pressure: interim report on wave-pressure research. Journal Institution of Civil Engineers 12, 201-206.

Bartrum, J.A., 1916. High water rock platforms: a phase of shore line erosion. Transactions and Proceedings of the New Zealand Institute 48, 132-134.

Bender, C.J., Dean, R.G., 2004. Potential shoreline changes induced by three-dimensional bathymetric anomalies with gradual transitions in depth. Coastal Engineering 51, 1143-1161.

Bird, E.C.F., Dent, O.F., 1966. Shore platforms on the south shore of New Wales. Australian Geographer 10, 71-80.

Boski, T., Moura, D., Veiga-Pires, C., Camacho, S., Duarte, D., Scott, D.B., Fernandes, S.G., 2002. Postglacial sea-level rise and sedimentary response in the Guadiana Estuary, Portugal/Spain border. Sedimentary Geology 150, 103-122.

Bradley, W.C., Griggs, C.B., 1976. Form, genesis and deformation of central California wave-cut platforms. Geological Society of American Bulletin 87 (3), 433-449.

Carter, N.E.A., Viles, H.A., 2005. Bioprotection explored: the story of a little known earth surface process. Geomorphology 67, 273-281.

Chao, R.B., Casais, M.C., Cortizas, A.M., Alberti, A.P., Trenhaile, A.S., 2003. Evolution and inheritance of a rock coast: Western Galicia, Northwestern Spain. Earth Surface Processes and Landforms 28, 757-775.

Cooper, J.A.G., Pilkey, O.H., 2004. Sea-level rise and shoreline retreat: time to abandon the Bruun Rule. Global and Planetary Change 43, 157-171.

Costa, M., 1994. Agitação marítima na costa portuguesa. Anais do Instituto Hidrográfico 13, 35-40 (Lisboa).

Costa, M.A.V., Teixeira, S.F.C.F., Teixeira, J.C.F., 2002. Roughness effects upon the near sediment turbulence patterns. In: Brebbia, C. A. (Ed.), Coastal Environment-Environmental Problems in Coastal Regions, vol. IV. WIT Press, Southampton, Boston, pp. 161-170.

Dias, J.M.A., 1988. Aspectos geológicos do Litoral Algarvio. Geonovas (Lisboa) 10, 113-128.

Dias, R.P., Cabral, J., 1998. Interpretação de estruturas dúcteis e frágeis afectando areias plio-quaternárias na região do Algarve a interferência da carsificação. Comunicações do Instituto Geológico e Mineiro 84, D77-D80 (Lisboa, t).

Dias, J.M.A., Neal, W.J., 1992. Sea cliff retreat in southern Portugal: profiles, processes, and problems. Journal of Coastal Research 8 (3), 641-654.

Dias, J.M.A., Taborda, R., 1992. Tidal gauge data in deducing secular trends of relative sea level and crustal movements in Portugal. Journal of Coastal Research 8 (3), 655-659.

Dickson, M.E., Woodroffe, C.D., 2002. Rocky coastline around Lord Howe Island and potential changes in the dynamics of coastal erosion with global climate change. Coast to Coast 2002 Conf. University of Wollongong, pp. 515-518.

Emery, K.O., Uchupi, E., 1972. Western north Atlantic Ocean: topography, rocks, structure, water, life and sediments. American Association of Petroleum Geologists Memoir 17 (532 pp.).

Gama, C., Dias, J.M.A., Ferreira, O., Taborda, R., 1994. Analysis of storm surge in Portugal. LITTORAL 94, pp. 26-29. Lisboa, Portugal.

Goodfellow, B.W., Stephenson, W.J., 2005. Beach morphodynamics in a strong-wind bay: a low-energy environment? Marine Geology $214(1-3), 101-116$.

\section{References}

Abreu, L., Shackleton, N.J., Schonfeld, J., Hall, M., Chapman, M., 2003. Millenial-scale oceanic climate variability off the western Iberian margin during the last two glacial periods. Marine Geology 196, 1-20.

Andrade, C., Marques, F., Freitas, M.C., Cardoso, R., Madureira, P., 2002. Shore platform downwearing and cliff retreat in the 
Griggs, G.B., Trenhaile, A.S., 1994. Coastal cliffs and platforms. In: Carter, R.W.G., Woodroffe, C.D. (Eds.), Coastal Evolution: Late Quaternary Shoreline Morphodynamics. Cambridge University Press, United Kingdom, pp. 425-476.

Havelock, T.H., 1940. The pressure of water waves upon a fixed obstacle. Proceedings of the Royal Society, London, A 175, 409-421.

Inman, D.L., Jenkins, S.A., Masters, P.M., 2003. Modeling platforms, terraces and coastal evolution. In: Schwartz, M. (Ed.), Encyclopedia of Coastal Science. Kluwer Academic Publishers, Dordrecht, The Netherlands. $1247 \mathrm{pp}$.

Instituto Hidrográfico, 1990. Roteiro da Costa de Portugal. Instituto Hidrográfico, Lisboa, p. 41.

Johnson, D.W., 1919. Shore Processes and Shoreline Development. Wiley, New York. 584 pp.

Kanyaya, J.I., Trenhaile, A.S., 2005. Tidal wetting and drying on shore platforms: an experimental assessment. Geomorphology 70 , 129-146.

Kelsey, H.M., Bockheim, J.G., 1994. Coastal landscape evolution as a function of eustasy and surface uplift rate, Cascadia margin, southern Oregon. Geological Society of American Bulletin 106 (6), 840-854.

Kershaw, S., Guo, L., 2001. Marine notches in coastal cliffs: indicators of relative sea-level change, Perachora Peninsula, Central Greece. Marine Geology 179, 213-228.

Komar, P.D., 1998. Beach Processes and Sedimentation, 2nd ed. Prentice-Hall, Upper Saddle River, NJ. 544 pp.

LaValle, P.D., Lakham, V.C., Trenhaile, A.S., 2001. Space-time series modelling of beach and shoreline data. Environmental Modelling \& Software 16, 299-307.

Marques, F.M.S. da F., 1997. As arribas do litoral do Algarve: dinâmica, processos e mecanismos. Ph.D. Thesis, Universidade de Lisboa, Portugal. 549 pp.

Naylor, L.A., Viles, H.A., 2002. A new technique for evaluating shortterm rates of coastal bioerosion and bioprotection. Geomorphology 47, 31-44.

Neves, M., Pereira, A.R., 1999. The interaction between marine and subaereal processes in the evolution of rocky coasts: the example of Castelejo (southwest Portugal). Boletin del Instituto Espanol de Oceanografia 15, 251-258.

Noormets, R., Crook, K.A.W., Felton, E.A., 2004. Sedimentology of rocky shorelines: 3 . Hydrodynamics of megaclast emplacement and transport on a shore platform, Oahu, Hawaii. Sedimentary Geology 172, 41-65.

Pereira, A.R., Dias, J.M.A., Laranjeira, M.M., 1993. Evolução Holocénica da Linha de Costa na Baía de Lagos. II Reunião do Quaternário Ibérico. Universidade de Coimbra, Coimbra, Portugal, pp. 75-89.

Pilkey Jr., O.H., Neal, W.J., Monteiro, J.H., Dias, J.M.A., 1989. Algarve barrier islands: a noncoastal-plain system in Portugal. Journal of Coastal Research 5 (2), 239-261.

Pirazzoli, P.A., 1986. Marine notches. In: Orson Van de Plassche (Eds.), Sea-Level Research: A Manual for the Collection and Evaluation of Data. Geo Books, Zurich, pp. 361-400.

Pirazzoli, P.A., Stiros, S.C., Arnold, M., Laborel, J., Laborel-Deguen, F., Papageorgiou, S., 1994. Episodic uplift deduced from Holocene shorelines in the Perachora Peninsula, Corinth area, Greece. Tectonophysics 229, 201-209.

Pires, H.N.O., 1989. O clima de Portugal. Alguns Aspectos do Clima de Agitação Marítima de Interesse para a Navegação na Costa de Portugal. Instituto Nacional de Meteorologia e Geofísica (INMG), Lisboa. $34 \mathrm{pp}$.
Pires, H.N.O., Pessanha, L.E.V., 1979. Agitação Marítima na Costa Portuguesa. Instituto Nacional de Meteorologia e Geofísica (INMG), Lisboa, pp. 1-13

Pires, H.N.O., Pessanha, L.E.V., 1986. Wave power climate of Portugal. In: Evans, D., Falcão, A.F.O. (Eds.), Hydrodynamics of Ocean Wave-Energy Utilization, IUTAM Symposium, Lisboa, pp. 157-167.

Ramírez-Herrera, M.T., Kostoglodov, V., Urrutia-Fucugauchi, J., 2004. Holocene-emerged notches and tectonic uplift along the Jalisco coast, Southwest Mexico. Geomorphology 58, 291-304.

Regnauld, H., Govery, P., Ferreira, O., Salieges, J.F., Gomes, N., 1994. Paleogeography of Weichsel and Holocene shorelines of Arrábida coast, central Portugal. Memorie Descrittive della Carta Geologica d'Italia LII, 295-308.

Roberts, H.M., Plater, A.J., 1999. U- and Th disequilibria in coastal infill sediments from Praia da Rocha (Algarve Region, Portugal): a contribution to the study of Late Quaternary weathering and erosion. Geomorphology 26, 223-238.

Sanders, J.E., Kumar, N., 1975. Evidence of shoreface retreat and inplace drowning during Holocene submergence of barriers, shelf off Fire Island, New York. Geological Society of America Bulletin 86, $65-76$

Short, A., 1999. Global variation in beach systems. In: Short, A. D. (Ed.), Handbook of Beach and Shoreface Morphodynamics. John Wiley \& Sons, LTD, West Sussex, England, pp. 21-35.

Stephenson, W.J., Kirk, R.M., 2000a. Development of shore platforms on Kaikoura Peninsula, South Island, New Zealand, Part one. The role of waves. Geomorphology 32, 21-41.

Stephenson, W.J., Kirk, R.M., 2000b. Development of shore platforms on Kaikoura Peninsula, South Island, New Zealand: II. The role of subaerial weathering. Geomorphology 32, 43-56.

Stephenson, W.J., Kirk, R.M., 2001. Surface swelling of coastal bedrock on inter-tidal shore platforms, Kaikoura Peninsula, South Island, New Zealand. Geomorphology 41, 5-21.

Sunamura, T., 1975. A laboratory model for wave-cut platform formation. Journal of Geology 83, 389-397.

Sunamura, T., 1996. A physical model for the rate of coastal tafoni development. The Journal of Geology 104, 741-748.

Teixeira, S.B., Pinto, C., 2002a. Radiocarbon ages of submerged and emerged beachrock in the Armação de Pêra Bay (AlgarvePortugal). $\mathrm{XI}^{\circ}$ Seminário Ibérico de Química Marinha, Faro, Portugal, pp. 72-73.

Teixeira, S.B., Pinto, C., 2002b. Submarine evidence of Holocene shoreline migration on Quarteira coast (Southern AlgarvePortugal). Littoral 22-26 (Porto, Portugal).

Trenhaile, A.S., 1987. The Geomorphology of Rock Coasts. Clarendon, Oxford, UK. 384 pp.

Trenhaile, A.S., 2000. Modeling the development of wave-cut shore platforms. Marine Geology 166, 163-178.

Trenhaile, A.S., 2001a. Modelling the effect of late Quaternary interglacial sea levels on wave-cut platforms. Marine Geology 172, 205-223.

Trenhaile, A.S., 2001b. Modeling the Quaternary evolution of shore platforms and erosional continental shelves. Earth Surface Processes and Landforms 26, 1103-1128.

Trenhaile, A.S., 2002a. Modeling the development of marine terraces on tectonically mobile rock coasts. Marine Geology 185 , 341-361.

Trenhaile, A.S., 2002b. Rock coasts, with particular emphasis on shore platforms. Geomorphology 48, 7-22. 
Trenhaile, A.S., 2005. Modelling the effect of waves, weathering and beach development on shore platform development. Earth Surface Processes and Landforms 30, 613-634.

Twidale, C.R., Bourne, J.A., Vidal Romani, J.R., 2005. Beach etching and shore platforms. Geomorphology 67 (1-2), 47-61.
Wentworth, C.K., 1938. Marine bench-forming processes-water level weathering. Journal of Geomorphology 1 (1), 5-32.

Wentworth, C.K., 1944. Potholes, pits, and pans: subaerial and marine. Journal of Geology 52 (2), 117-130. 